\title{
Globalization And Time Varying Prices Of Market And Foreign Exchange Risks: Canadian Evidence
}

Sarath Abeysekera, (Email: Sarath_Abeysekera@Umanitoba.ca), University of Manitoba, Canada Sergiy Rakhmayil, (Email: srakhmay@ryerson.ca), Ryerson University, Canada

\begin{abstract}
The paper empirically examines the relationship between stock returns, exchange rate, and market risks for the Canadian stock market operating in an increasingly global environment. Time varying prices of market and currency risks and corresponding risk premia are estimated. We investigate how estimated risk premia in different industry sectors are affected by macroeconomic events associated with globalization. We find that magnitude of shocks is greater, and risk premia at the times of economic shocks are greater in the post-1994 than in pre-1994 period, and this increase seems to be driven by the increased market exposure of stock returns.
\end{abstract}

Keywords: globalization, currency risk, market risk

\section{INTRODUCTION}

iven Canada's heavy reliance on international product and capital markets, all Canadian firms are directly and indirectly exposed to foreign exchange rate risk, regardless of whether their operations are domestic or multinational. Various regulatory, and institutional changes accompanied by increased globalization of commerce is generally expected to have a major impact on trade-oriented economies such as Canada. Performance of firms listed in Toronto Stock Exchange, therefore, can be thought of as barometers measuring the impact of these ongoing changes in the Canadian market.

The main purpose of this paper is to estimate the influences of the market and foreign exchange risks on stock returns in Canada. We employ the multifactor pricing framework based on the CAPM of Sharpe $(1964,1965)$ and international asset pricing model (IAPM) of Adler and Dumas (1983). The model is estimated with a sample of five industry portfolios, an equally weighted index, and US\$ exchange rate changes using monthly data starting in August 1976 and ending in December 2001. The prices of risk and risk premia are recovered by jointly estimating a seven-variate model based on the conditional IAPM of De Santis and Gerard (1998).

Initial view of the trade agreements such as Free Trade Agreement (FTA) and North American Free Trade Agreement (NAFTA) attributed abnormal stock returns to expect gains from comparative advantages and economies of scale for participating countries. ${ }^{i}$ The U.S. economic recession of 2001-2003 revived the discussion regarding the costs and benefits of NAFTA. For instance, Hansen and Song (2002) report insignificant or negative effects of the agreement on U.S. industries and positive effects on Mexican industries. Rodriguez (2003) found strong evidence that capital-intensive U.S. companies were expected to benefit from NAFTA and similar but weaker results for Canadian industries. Most of these studies utilized event study technique to uncover the effects of political news on stock returns.

Our study is intended to contribute to the extent literature in two fronts. First, we study five industry portfolios of Canadian stocks with a view to understanding the implications of growing internationalization with a primary focus on the Canadian investor. Second, the employment of De Santis and Gerard (1998) methodology enables us to test the pricing restrictions and to study the relative magnitude and the dynamics of both currency and 
market risk premia applicable to Canadian market. To the best of our knowledge, this is the first paper that analyzes the effect of globalization in Canada by uncovering dynamics of prices of market and currency risks and corresponding risk premia jointly at the industry level, as opposed to event study techniques employed in earlier research. We view liberalization as a gradual process and use implementation of NAFTA in January 1994 merely as a logical division point between two subperiods, pre-1994 (lower degree of liberalization) and post-1994 (higher degree of liberalization). We by no means imply that the changes in market pricing found in this study occurred instantly on January 1994 and solely because of NAFTA.

We explicitly model the time varying aspect of the risk premia by employing a multivariate generalized autoregressive conditional heteroscedastic (MGARCH) framework. The MGARCH framework resolves some of the problems present in the univariate models. In particular, MGARCH makes it possible to estimate model parameters jointly, thus allowing for multivariate error distribution. Common MGARCH representations include Vech, diagonal, constant conditional correlation, BEKK in Engle and Kroner (1995), and others such as in Gourieroux and Jasiak (2001). , $^{\mathrm{i}, \mathrm{iii}}$ These models have been successfully applied to economic problems. Recent studies include Turtle et al. (1994), Karolyi and Stulz (1996), Kroner and Ng (1998), Tse (2000), and Engle (2002), among others.

Our investigation of how estimated risk prices and risk premia in Canada are affected by macroeconomic events associated with globalization finds strong evidence that the prices of currency and market risk are timevarying. We find that the price of currency risk is a significant component of asset pricing in the Canadian market. We also find evidence that globalization had significant impact on pricing in the Canadian stock market. The prices of market and exchange rate risks exhibit increased variability over recent years suggesting increased influence of external factors on Canadian stock prices. Market and currency premia for all industry sectors also exhibit similar pattern, although the magnitudes of the effect are industry-specific.

The rest of the paper is organized as follows. In the next section the econometric method used in this study is developed. Section III describes the data and Section IV reports the results and discusses the empirical evidence. Section V concludes the paper.

\section{MODEL AND METHODOLOGY}

We analyze the conditional version of a multifactor model that incorporates both market risk and currency risk. The market risk is a well known risk factor since the Capital Asset Pricing Model of Sharpe (1964), and the concept of currency risk was originally developed by Adler and Dumas (1983). Dumas and Solnik (1995) and De Santis and Gerard (1998), among others, present ample evidence of the significance of the currency risk in pricing stock returns.

The theoretical relationship investigated in this paper is:

$E\left[r_{i}\right]=\lambda_{F X} \sigma_{i, F X}+\lambda_{M} \sigma_{i, M}$,

where, $r_{i} \equiv\left(\tilde{r}_{i}-r_{f}\right)$ is excess return over the riskless rate, $\sigma_{i, M}$ is the instantaneous covariance between the excess returns of asset $i$ and the market excess return, $\sigma_{i, F X}$ is the instantaneous covariance between the excess returns of asset $i$ and change in the exchange rate $\tilde{r}_{F X}$ in excess of the riskless rate, $\lambda_{F X}$ is the price of foreign exchange risk and $\lambda_{M}$ is the price of market risk. Both prices of risk are assumed to depend on relative risk aversion of investors within a country. We assume that prices of currency and market risks are determined within the aggregate national capital market and are the same within specific market segments. In this study segments of Canadian stock market are represented by excess returns of five randomly selected industry indices. Canadian market portfolio is proxied by CFMRC equally weighted index. ${ }^{\text {iv }}$ A series of exchange rate changes represents the foreign exchange rate risk of Canadian companies. ${ }^{\mathrm{V}}$ The model is as follows: 


$$
\begin{aligned}
& r_{i, t}=\lambda_{M, t-1} \operatorname{cov}_{t-1}\left(r_{i, t}, r_{M, t}\right)+\lambda_{F X, t-1} \operatorname{cov}_{t-1}\left(r_{i, t}, r_{F X, t}\right)+e_{i, t}, i=1, \ldots, 5 \\
& r_{M, t}=\lambda_{M, t-1} \operatorname{var}_{t-1}\left(r_{M, t}\right)+\lambda_{F X, t-1} \operatorname{cov}_{t-1}\left(r_{M, t}, r_{F X, t}\right)+e_{M, t}, \\
& r_{F X, t}=\lambda_{M, t-1} \operatorname{cov}_{t-1}\left(r_{F X, t}, r_{M, t}\right)+\lambda_{F X, t-1} \operatorname{var}_{t-1}\left(r_{F X, t}\right)+e_{F X, t}, \\
& e_{1, t}, \ldots, e_{5, t}, e_{M, t}, e_{F X, t} \sim N\left(0, \mathbf{H}_{t}\right)
\end{aligned}
$$

where,

$$
\begin{aligned}
& \lambda_{M, t-1}=\exp \left[k_{1,0}+k_{1,1} \cdot z_{1, t-1}+k_{1,2} \cdot z_{2, t-1}+k_{1,3} \cdot z_{3, t-1}+k_{1,4} \cdot z_{4, t-1}\right] \\
& \lambda_{F X, t-1}=k_{2,0}+k_{2,1} \cdot z_{1, t-1}+k_{2,2} \cdot z_{2, t-1}+k_{2,3} \cdot z_{3, t-1}+k_{2,4} \cdot z_{4, t-1}
\end{aligned}
$$

We use instrumental variables $z_{i, t}, i=1, \ldots, 4$ that include term premium (TP), default premium (DP), dividend yield (DY), and previous month's market excess return, $r_{M, t-1}$. We also restrict the price of market risk to be positive by using an exponential function in (5), and make no such restriction on the price of foreign exchange risk in (6). ${ }^{\mathrm{vi}}$

Dynamic variance-covariance matrix is specified as diagonal BEKK with variance targeting which, according to Engle and Mezrich (1996), improves performance of the estimator in finite samples and reduces the number of parameters. Therefore, we estimate the following specification of $\mathbf{H}_{t}$ :

$\mathbf{H}_{t}=\mathbf{H}_{0} \circ\left(\mathbf{i i}^{\prime}-\mathbf{a a}^{\prime}-\mathbf{b b}^{\prime}\right)+\mathbf{a e}_{t-1} \mathbf{e}_{t-1}^{\prime} \mathbf{a}^{\prime}+\mathbf{b} \mathbf{H}_{t-1} \mathbf{b}^{\prime}$

where, $\mathbf{H}_{0}$ is unconditional $7 \times 7$ variance-covariance matrix, “o" denotes Hadamard product, $\mathbf{i}$ is a $7 \times 1$ vector of ones, and finally $\mathbf{a}$ and $\mathbf{b}$ are diagonal matrices of coefficients with respective elements denoted by $\alpha_{1}, \ldots, \alpha_{7}$, and $\beta_{1}, \ldots, \beta_{7}$. The system is estimated using the Marquardt algorithm under assumption of multivariate normality. ${ }^{\text {vii }}$

\section{DATA AND SUMMARY STATISTICS}

We employ a sample of five Canadian industry sector indices of firms listed in the Toronto Stock Exchange along with the equally weighted TSX300 index as a proxy for the market portfolio. This data is obtained from the Canadian Financial Market Research Centre (CFMRC). The three-month Canadian Treasury bill yield is used as the risk free rate. Based on the availability of data, we limit our study period to 215 monthly observations starting in February 1984 and ending in December 2001. ${ }^{\text {viii }}$ Excess returns are obtained by subtracting the three-month Canadian Treasury bill yield. We use the U.S. dollar exchange rate, expressed in Canadian dollars per U.S. dollar.

Following Dumas and Solnik (1995), De Santis and Gerard (1998), and Carrieri et al. (2003) we use five information (instrumental) variables in our estimation procedure. These include a constant, change in the exchange rate (XR), dividend yield in excess of the risk free rate (DY), term premium on Canadian Government bonds (TP), default premium of corporate bonds (DP), and the lagged excess return on the market portfolio $\left(r_{M, t-1}\right)$. DP is measured by the yield difference between Moody's Baa-rated and aa-rated bonds. ${ }^{\mathrm{ix}} \mathrm{TP}$ is measured by the difference between the long-term Government of Canada 10-year maturity bonds and the three-month Treasury bill rates.

Table 1 reports the descriptive statistics of the key variables. Panel A reports the summary statistics for the excess return series of five industry indices, the market index and the change in exchange rate. The table indicates strong evidence that the data series do not conform to the assumptions of normality. This conclusion is based on the fact that all unconditional sample skewness measures are significantly different from zero, and the kurtosis measures are significantly larger than the critical value of three. Furthermore, Jarque-Berra and ADF tests reject the 
hypothesis that the series are normal at zero level of significance. Rejection of the normality assumption on the data series is inconsistent with linearity and constancy of the conditional variance, and it suggests the appropriateness of GARCH modeling in analyzing the series.

Table 2 reports the descriptive statistics of the information variables. Again, the skewness and kurtosis measures indicate non-normality of all five series. Jarque-Berra and ADF tests for the normality of the series also reject the hypothesis that the series are normal at zero level of significance.

Table 1

Descriptive Statistics of Data Series

Panel A: Descriptive Statistics

\begin{tabular}{|c|c|c|c|c|c|c|c|}
\hline & $\begin{array}{c}\text { Metals and } \\
\text { Mining } \\
\end{array}$ & Oil and Gas & $\begin{array}{c}\text { Industrial } \\
\text { Products }\end{array}$ & Conglomerates & $\begin{array}{l}\text { Consumer } \\
\text { Products }\end{array}$ & $\begin{array}{c}\begin{array}{c}\text { Market Index } \\
\text { Return }^{\text {a }}\end{array} \\
\end{array}$ & Currency $^{b}$ \\
\hline Mean & 0.0016 & 0.0021 & 0.0021 & 0.0051 & 0.0059 & 0.0091 & -0.0048 \\
\hline Median & 0.0007 & 0.0026 & 0.0015 & 0.0026 & 0.0056 & 0.0061 & -0.0057 \\
\hline Maximum & 0.2344 & 0.2286 & 0.2341 & 0.1537 & 0.1488 & 0.3670 & 0.0280 \\
\hline Minimum & -0.3145 & -0.2271 & -0.3865 & -0.2294 & -0.2326 & -0.2936 & -0.0295 \\
\hline Std. Dev. & 0.0723 & 0.0661 & 0.0755 & 0.0566 & 0.0511 & 0.0629 & 0.0116 \\
\hline Skewness & -0.1353 & 0.1820 & -0.5714 & -0.1338 & -0.8079 & 0.4268 & 0.2745 \\
\hline Kurtosis & 4.7807 & 4.2993 & 6.7848 & 4.2711 & 6.1993 & 10.2706 & 2.5374 \\
\hline \multicolumn{8}{|c|}{ Panel B: Correlations } \\
\hline & $\begin{array}{l}\text { Metals and } \\
\text { Mining }\end{array}$ & Oil and Gas & $\begin{array}{c}\text { Industrial } \\
\text { Products }\end{array}$ & Conglomerates & $\begin{array}{c}\text { Consumer } \\
\text { Products }\end{array}$ & $\begin{array}{l}\text { Market Index }{ }^{\mathrm{a}} \\
\text { Return }\end{array}$ & Currency $^{\mathbf{b}}$ \\
\hline Metals and Mining & 1.0000 & & & & & & \\
\hline Oil and Gas & 0.4929 & 1.0000 & & & & & \\
\hline Industrial Products & 0.4303 & 0.2016 & 1.0000 & & & & \\
\hline Conglomerates & 0.6342 & 0.5333 & 0.4463 & 1.0000 & & & \\
\hline Consumer Products & 0.4098 & 0.2392 & 0.6158 & 0.5377 & 1.0000 & & \\
\hline Market Index & 0.5133 & 0.5161 & 0.5780 & 0.5364 & 0.5406 & 1.0000 & \\
\hline Currency & -0.2053 & -0.0858 & -0.1839 & -0.1921 & -0.1702 & -0.2108 & 1.0000 \\
\hline
\end{tabular}

\section{EMPIRICAL RESULTS}

We estimate the multivariate model outlined by equations 1,2 and 3 , and the results are reported in Table $3^{\mathrm{x}}$. Panels A and B report parameter estimates for the mean equations. Coefficients for the market index for both market and currency risks are both positive and significant, which may indicate that high market returns in the past are expected to increase both market and currency risk premia. This result is consistent with increasing relative risk aversion of investors. Individual significance of the coefficients related to the other information variables is relatively low, possibly due to high cross-correlation of the returns and information variables, reported in Table 1 and Table 2, which may have led to high multicolinearity. Panels $\mathrm{C}$ and $\mathrm{D}$ report the conditional variance processes. Panel E reports the results of diagnostic tests. As shown in Panel A, three of the five coefficients are statistically significant, indicating that the market premium of risk is a significant factor in asset pricing. The mean equation coefficients associated with foreign exchange rate reported in Panel B, show that the coefficient associated with market is significant. ${ }^{\mathrm{xi}}$ 
Table 2

Descriptive Statistics of Information Variables

Panel A: Descriptive Statistics

\begin{tabular}{|c|c|c|c|c|}
\hline & $\begin{array}{c}\text { Market Index Return } \\
(\mathrm{t}-1)\end{array}$ & $\begin{array}{c}\text { Change in Term } \\
\text { Premium (t-1) }\end{array}$ & $\begin{array}{l}\text { Change in Default } \\
\text { Premium (t-1) } \\
\end{array}$ & $\begin{array}{c}\text { Change in Dividend } \\
\text { Yield }(\mathrm{t}-1)^{\mathrm{a}} \\
\end{array}$ \\
\hline Mean & 0.0087 & 0.0000 & 0.0001 & 0.0000 \\
\hline Median & 0.0059 & 0.0002 & 0.0000 & 0.0000 \\
\hline Maximum & 0.3670 & 0.0132 & 0.0247 & 0.0006 \\
\hline Minimum & -0.2936 & -0.0234 & -0.0111 & -0.0004 \\
\hline Std. Dev. & 0.0628 & 0.0049 & 0.0027 & 0.0001 \\
\hline Skewness & 0.4434 & -1.0429 & 2.9632 & 0.6401 \\
\hline Kurtosis & 10.3539 & 6.9992 & 36.8707 & 7.2691 \\
\hline Jarque-Bera & 491.5038 & 182.2454 & 10591.8400 & 177.9531 \\
\hline Probability & 0.0000 & 0.0000 & 0.0000 & 0.0000 \\
\hline ADF & $-11.8403^{* * * *}$ & $-8.3710^{* * * *}$ & $-15.7775^{* * * *}$ & $-14.5505^{* * * *}$ \\
\hline Probability & 0.0000 & 0.0000 & 0.0000 & 0.0000 \\
\hline ADF of Levels ${ }^{b}$ & $-11.8403^{* * *}$ & -2.4782 & $-2.7290^{*}$ & -1.0874 \\
\hline Probability & 0.0000 & 0.1222 & 0.0708 & 0.7209 \\
\hline Observations & 215 & 215 & 215 & 215 \\
\hline \multicolumn{5}{|c|}{ Panel B: Correlations } \\
\hline $\begin{array}{c}\text { Market Index Return } \\
(\mathrm{t}-1)\end{array}$ & 1.0000 & & & \\
\hline $\begin{array}{l}\text { Change in Term } \\
\text { Premium (t-1) }\end{array}$ & 0.0396 & 1.0000 & & \\
\hline $\begin{array}{l}\text { Change in Default } \\
\text { Premium(t-1) }\end{array}$ & -0.1237 & -0.1488 & 1.0000 & \\
\hline $\begin{array}{l}\text { Change in Excess } \\
\text { Dividend Yield(t-1) }\end{array}$ & -0.6204 & 0.0785 & 0.0479 & 1.0000 \\
\hline
\end{tabular}

These results suggest that both the market and currency risks are significant factors in pricing of Canadian stocks. This finding is consistent with those of Dumas and Solnik (1995) who find that the currency risk is a significant factor in international asset pricing.

Panel C and D of Table 3 reveal that all parameter estimates associated with the ARCH and GARCH processes are statistically significant. Consistent with the results of De Santis and Gerard (1998), our GARCH coefficients are considerably larger than the corresponding ARCH coefficients. This indicates that the current second moment is more influenced by its own lagged value than past innovations. Bollerslev (1986) shows that for each process in $H_{t}$ to be stationary, the condition $\alpha_{i} \alpha_{j}+\beta_{i} \beta_{j}<1$ has to be satisfied. Panel E of Table 3 presents model diagnostics, which shows that the model is adequate.

Table 4 reports the probabilities of Ljung-Box Statistics of residuals associated with five, ten, fifteen and twenty-period lags. High p-values reported in panel A for standard residuals indicate adequacy of the corresponding mean equations. High p-values of squared residuals reported in Panel B indicate adequacy of the corresponding variance equations. 
Results of Likelihood ratio tests of the main hypotheses examined in this study are reported in Table 5. We estimated a number of restricted models and compared log likelihood with unrestricted models. The unrestricted model in Table 5 is the one whose output is in Table 3. Restricted models have (1) no market price of risk, (2) a constant as market price of risk, (3) no currency risk coefficients, and (4) a constant as price of currency risk. All hypotheses are rejected at the $1 \%$ level, indicating that both prices of risk are significant and time varying.

Table 6 reports the descriptive statistics of price of risk. The range of the market price of risk is generally within the range graphed in Dumas and Solnik (1995). The mean price of market risk and currency risk are 3.9015 and 1.9513 respectively. The price of market risk and the price of currency risk reported here are comparable to those of Carrieri et al. (2003) and De Santis and Gerard (1998). The estimated price of the currency risk is more volatile: the standard deviation of the price of market risk is 7.1038, while the standard deviation of the price of the currency risk is 13.3469. Furthermore, the range for the price of market risk is 97.6438 (from 0.2372 to 97.8810 ) while the range for the price of currency risk is 154.634 (from -56.7527 to 76.4921 ).

Exhibit 1 presents the estimated trajectories of the prices of the market and foreign exchange risks in the Canadian market. De Santis and Gerard (1998) point out that these estimates are volatile and subject to estimation error. Therefore, more attention needs to be paid to the general trend than to a plotted value at a given point in time. Following their suggestion we plot Hodrick-Prescott (HP) filtered prices. ${ }^{\text {xii }}$ Examination of the graphs reveals three large spikes in the price of the market risk. The first spike takes place in late 1987, the second occurs around 1993, and the last spike is around 1997. We hypothesize that these spikes are related to the 1987 US stock market crash, the currency crises in the European Monetary System in 1992-1993, and to the Asian Flu in 1997-1998. Note that the spikes in the price of Canadian market risk grow in magnitude: the smallest is in 1987, the spike in 1993 is larger than the previous, and the largest is in 1997. Examination of the time path of the Canadian price of currency risk also reveals a number of spikes that mostly correspond to the spikes in the price of the market risk. In general, we observe that the magnitude of spikes increased in recent years for the prices of both market and currency risks.

A similar picture emerges when we examine time paths of estimated risk premia for the market index, the currency index, and five industry portfolios presented in Exhibit 2. Even though the estimated magnitudes of the spikes for risk premia differ from industry to industry, in all cases one could see larger peaks in the market risk premium, currency premium, and total premiums taking place in recent years. ${ }^{\text {xiii }}$ Table 7 presents medians for top and bottom deciles of the estimated risk premia ${ }^{\text {xiv }}$. It clearly shows that the differences between the top and bottom deciles become larger for the second subperiod, indicating that magnitude of the shocks in the second subperiod grew larger. For example, the difference between the top and bottom market premium deciles for Metals and Mining is $0.0234-0.0024=0.0210$ for the first subsample and $0.1592-0.0020=0.1571$ for the second subsample. One could speculate that as markets became more liberalized in recent years, the impact of external shocks on the Canadian stock market became larger ${ }^{\mathrm{xv}}$.

However, the question remains whether these shocks had a lasting effect on the Canadian markets by causing statistically significant changes in affecting average values of the risk prices, risk exposures, and the risk premia. To formally investigate whether distributional characteristics of the prices of risks and risk premia changed over time, we follow De Santis et al (2003). We divide the sample into two sub-samples around January 1994 and test whether means of key data series remained the same across the subsamples ${ }^{\text {xvi }}$. We study whether estimated total, market, and currency premiums changed as the process of globalization progressed. Table 8 shows that no statistically significant change in the average risk premia was detected, even though the economic significance of the changes is evident: estimated average change in the total risk premium for the Market index is 0.0912, which is almost 6 times the estimated pre-1994 value of $0.0153^{\text {xvii }}$. We conjecture that no significant changes in the average risk premia are observed because the capital markets may have already adjusted, on average, to the new political environment, taking into account that the timeline of the political events is known far in advance. ${ }^{\text {xviii }}$ 
Table 3

Parameter Estimates

The estimated model is as follows:

$$
\begin{aligned}
& r_{i, t}=\lambda_{M, t-1} \operatorname{cov}_{t-1}\left(r_{i, t}, r_{M, t}\right)+\lambda_{F X, t-1} \operatorname{cov}_{t-1}\left(r_{i, t}, r_{F X, \cdots t}\right)+e_{i, t}, i=1, \ldots, 5 \\
& r_{M, t}=\lambda_{M, t-1} \operatorname{var}_{t-1}\left(r_{M, t}\right)+\lambda_{F X, t-1} \operatorname{cov}_{t-1}\left(r_{M, t}, r_{F X, t}\right)+e_{M, t}, \\
& r_{F X, t}=\lambda_{M, t-1} \operatorname{cov}_{t-1}\left(r_{F X, t}, r_{M, t}\right)+\lambda_{F X, t-1} \operatorname{var}_{t-1}\left(r_{F X, t}\right)+e_{F X, t}, \\
& e_{1, t}, \ldots, e_{5, t}, e_{M, t}, e_{F X, t} \sim N\left(0, \mathbf{H}_{t}\right) \\
& \text { where, } \\
& \lambda_{M, t-1}=\exp \left[k_{1,0}+k_{1,1} \cdot z_{1, t-1}+k_{1,2} \cdot z_{2, t-1}+k_{1,3} \cdot z_{3, t-1}+k_{1,4} \cdot z_{4, t-1}\right] \\
& \lambda_{F X, t-1}=k_{2,0}+k_{2,1} \cdot z_{1, t-1}+k_{2,2} \cdot z_{2, t-1}+k_{2,3} \cdot z_{3, t-1}+k_{2,4} \cdot z_{4, t-1}
\end{aligned}
$$

Instrumental variables $z_{i, t}, i=1, \ldots, 4$ are previous month's market excess return, $r_{M, t-1}$, change in term premium (TP), change in default premium (DP), and change in dividend yield (DY). Price of market risk is restricted to be positive by using exponential function in (4). No such restriction on the price of foreign exchange risk in (5).

Panel A: Mean Equation Coefficients Associated with Market Index

\begin{tabular}{cccccc}
\hline & Constant & Market & TP & DP & DY \\
\hline Coefficient & $0.9434^{* * * *}$ & $9.7423^{* * * *}$ & $72.2883^{*}$ & -22.2137 & 258.7240 \\
Std. Error & 0.2468 & 0.4750 & 41.4146 & 47.6289 & 726.6872 \\
t-stats & 3.8219 & 20.5122 & 1.7455 & -0.4664 & 0.3560 \\
\hline
\end{tabular}

Panel B: Mean Equation Coefficients Associated with Foreign Exchange Rate

\begin{tabular}{cccccc}
\hline & Constant & Market & TP & DP & DY \\
\hline Coefficient & $0.1334^{* * * *}$ & $205.2877^{*}$ & 609.7279 & 45.6792 & -78.3020 \\
Std. Error & 0.6038 & 110.6441 & 1234.2847 & 208.8903 & 217.2016 \\
t-stats & 0.2208 & 1.8554 & 0.4940 & 0.2187 & -0.3605 \\
\hline
\end{tabular}

Panel C: ARCH Coefficients

\begin{tabular}{cccccccc}
\hline & alpha(1) & alpha(2) & alpha(3) & alpha(4) & alpha(5) & alpha(6) & alpha(7) \\
\hline Coefficient & $0.3885^{* * * *}$ & $0.5127^{* * *}$ & $0.3320^{* * * *}$ & $0.2396^{* * * *}$ & $0.1638^{* * * *}$ & $0.3605^{* * * *}$ & $0.2307^{* * * *}$ \\
Std. Error & 0.0590 & 0.0521 & 0.0261 & 0.0447 & 0.0272 & 0.0356 & 0.0679 \\
t-stats & 6.5790 & 9.8357 & 12.7374 & 5.3588 & 6.0126 & 10.1122 & 3.3953 \\
\hline
\end{tabular}

Panel D: GARCH Coefficients

\begin{tabular}{cccccccc}
\hline & beta $(1)$ & beta $(2)$ & beta $(3)$ & beta $(4)$ & beta(5) & beta $(6)$ & beta(7) \\
\hline Coefficient & $0.5210^{* * * *}$ & $0.5110^{* * * * * * * *}$ & $0.9183^{* * *}$ & $0.8282^{* * * *}$ & $0.9789^{* * * *}$ & $0.5379^{* * * *}$ & $0.6762^{* * * *}$ \\
Std. Error & 0.1527 & 0.1354 & 0.0126 & 0.0051 & 0.0089 & 0.0904 & 0.1976 \\
t-stats & 3.4113 & 3.7750 & 72.8608 & 161.5653 & 110.4060 & 5.9527 & 3.4224 \\
\hline
\end{tabular}

\section{Panel E: Diagnostics}

\begin{tabular}{cc}
\hline Log Likelihood & $\mathbf{3 6 0 0 . 9 1 1 2}$ \\
\hline Number of observations & 215 \\
Number of coefficients & 24 \\
Akaike information criterion & -33.2735 \\
Schwarz criterion & -32.8973 \\
Hannan-Quinn criterion. & -33.1215 \\
${ }^{* * * * *}$ indicates 1\% significance, ${ }^{* *}$ indicates 5\% significance, ${ }^{*}$ indicates $10 \%$ significance level.
\end{tabular}


A greater degree of liberalization could imply a greater exposure to outside shocks. To further investigate whether or not external shocks affected Canadian capital markets in the earlier sub-period the same way as in the later sub-period, we conduct tests for mean changes for the outliers only, keeping in mind that at the times of economic shocks capital market variables tend to exhibit extreme values. For the prices of market and currency risks, risk exposures, and risk premia, we construct series that include only bottom 5\% and top 5\% of the observations for each subsample. We present tests for the structural breaks between pre-1994 and post-1994 in period's average risk premia for the outliers in Table 9. It shows significant increases in the total risk premia for 6 out of 7 stock indices. For example, an increase in the average total premium at the times of economic shocks in the post-1994 period was 0.7438 for the market index, with the corresponding t-value of 2.0564 . We also observe increases in the market and currency premia, although many of the estimated changes are not statistically significant. Examination of Table 10 shows no significant change in the average prices of market or currency risks, while Table 11 shows significant increase for all 7 cases in the average market exposure and significant decrease for 4 out of 7 cases for average currency exposure during turbulent periods. Thus, the average increases in the total risk premia at the times of economic shocks seem to be associated by increased average market exposure of Canadian stock returns.

\section{CONCLUSION}

The paper empirically examines importance of the exchange rate and market risks in Canadian stock markets. Canadian equity portfolio returns and other economic data are used in a multivariate GARCH-M framework to capture the time varying aspects of price of exchange rate risk. We find strong evidence that prices of currency and market risks are time-varying. This is consistent with current literature including De Santis and Gerard (1998), Dumas and Solnik (1995) and Carrieri et al. (2003). Our results indicate that price of currency risk is a significant component of asset pricing in the Canadian market. Also, it is the market risk premia that dominate the total risk. We find evidence that the magnitude of economic shocks in the Canadian markets increased after 1994. We discover evidence of significant structural changes in average risk premia and market exposures during pre-1994 versus post-1994 crises. Increased market liberalization leads to a greater degree of interdependence and less effective diversification, and subsequently higher than pre-1994 systematic risk premia at the times of shocks.

Table 4

Probabilities of Ljung-Box Q statistics of Residuals

\begin{tabular}{cccccccc}
\multicolumn{2}{l}{ Panel A: Residuals } & \multicolumn{1}{c}{ (1) } \\
\hline Series: & $\begin{array}{c}\text { Met. \& } \\
\text { Mining }\end{array}$ & Oil \& Gas & Ind. Products & Conglomerates & $\begin{array}{c}\text { Cons. } \\
\text { Products }\end{array}$ & Market Index & Currency \\
\hline Lags & Res1 & Res2 & Res3 & Res4 & Res5 & Res6 & Res7 \\
\hline 5 & 0.819 & 0.538 & 0.235 & 0.533 & 0.756 & 0.720 & 0.001 \\
10 & 0.860 & 0.780 & 0.475 & 0.673 & 0.624 & 0.899 & 0.000 \\
15 & 0.964 & 0.750 & 0.139 & 0.676 & 0.884 & 0.927 & 0.000 \\
20 & 0.921 & 0.766 & 0.362 & 0.613 & 0.912 & 0.968 & 0.000 \\
\hline
\end{tabular}

Panel B: Squared Residuals

\begin{tabular}{cccccccc}
\hline & Sq. Res1 & Sq. Res2 & Sq. Res3 & Sq. Res4 & Sq. Res5 & Sq. Res6 & Sq. Res7 \\
\hline 5 & 0.501 & 0.675 & 0.755 & 0.643 & 0.864 & 0.269 & 0.891 \\
10 & 0.890 & 0.963 & 0.976 & 0.898 & 0.987 & 0.770 & 0.890 \\
15 & 0.980 & 0.997 & 0.999 & 0.980 & 0.997 & 0.965 & 0.965 \\
20 & 0.985 & 0.999 & 1.000 & 0.938 & 0.937 & 0.996 & 0.276 \\
\hline
\end{tabular}

Note: Residuals are standardized by fitted standard deviation, squared residuals are standardized by variance, and product residuals are standardized by corresponding covariance. 
Table 5

Tests of Price of Risk

\begin{tabular}{|c|c|c|c|}
\hline Hypothesis/Restriction & LR Test Statistic & Degrees of Freedom & p-value \\
\hline $\begin{array}{l}\text { 1. Price of market risk is Zero } \\
\mathrm{k}_{1,1}=\mathrm{k}_{1,2}=\mathrm{k}_{1,3}=\mathrm{k}_{1,4}=\mathrm{k}_{1,5}=0\end{array}$ & $16395.12^{* * * *}$ & 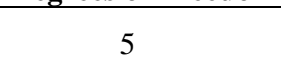 & 0.0000 \\
\hline $\begin{array}{l}\text { 2. Price of market risk is Constant } \\
\mathrm{k}_{1,2}=\mathrm{k}_{1,3}=\mathrm{k}_{1,4}=\mathrm{k}_{1,5}=0\end{array}$ & $597.6529^{\text {**** }}$ & 4 & 0.0000 \\
\hline $\begin{array}{l}\text { 3. Price of currency risk is Zero } \\
\mathrm{k}_{2,1}=\mathrm{k}_{2,2}=\mathrm{k}_{2,3}=\mathrm{k}_{2,4}=\mathrm{k}_{2,5}=0\end{array}$ & $12.4039^{* *}$ & 5 & 0.0297 \\
\hline $\begin{array}{l}\text { 4. Price of currency risk is Constant } \\
\mathrm{k}_{2,2}=\mathrm{k}_{2,3}=\mathrm{k}_{2,4}=\mathrm{k}_{2,5}=0\end{array}$ & $12.2957^{* *}$ & 4 & 0.0153 \\
\hline $\begin{array}{l}\text { 5. ARCH elements are irrelevant } \\
\mathrm{a}(\mathrm{i})=0, \mathrm{i}=1, \ldots, 7\end{array}$ & $435.0669^{* * *}$ & 7 & 0.0000 \\
\hline $\begin{array}{l}\text { 6. GARCH elements are irrelevant } \\
b(\mathrm{i})=0, \mathrm{i}=1, \ldots, 7\end{array}$ & $116257.3^{* * * *}$ & 7 & 0.0000 \\
\hline $\begin{array}{l}\text { 7. Variance is constant } \\
\mathrm{a}(\mathrm{i})=0, \mathrm{~b}(\mathrm{i})=0, \mathrm{i}=1, \ldots, 7\end{array}$ & $2.37 \mathrm{E}+08^{* * *}$ & 14 & 0.0000 \\
\hline
\end{tabular}

${ }^{* * *}$ indicates $1 \%$ significance, ${ }^{* *}$ indicates $5 \%$ significance, ${ }^{*}$ indicates $10 \%$ significance level.

Table 6

Descriptive Statistics of Prices of Risk

\section{Mkt Risk Price}

3.9015

$$
2.7250
$$

97.8810

0.2372

Maximum

Minimum

Dev.

Skewness

Kurtosis

Jarque-Bera

Probability

Observations
7.1038

11.1135

144.6209

184098.4

0.0000

215

\section{FX Risk Price}

1.9513

0.5175

76.4921

$-56.7527$

13.3469

0.5946

8.8839

322.8122

0.0000

\section{Exhibit 1: Estimated Prices of Risks}
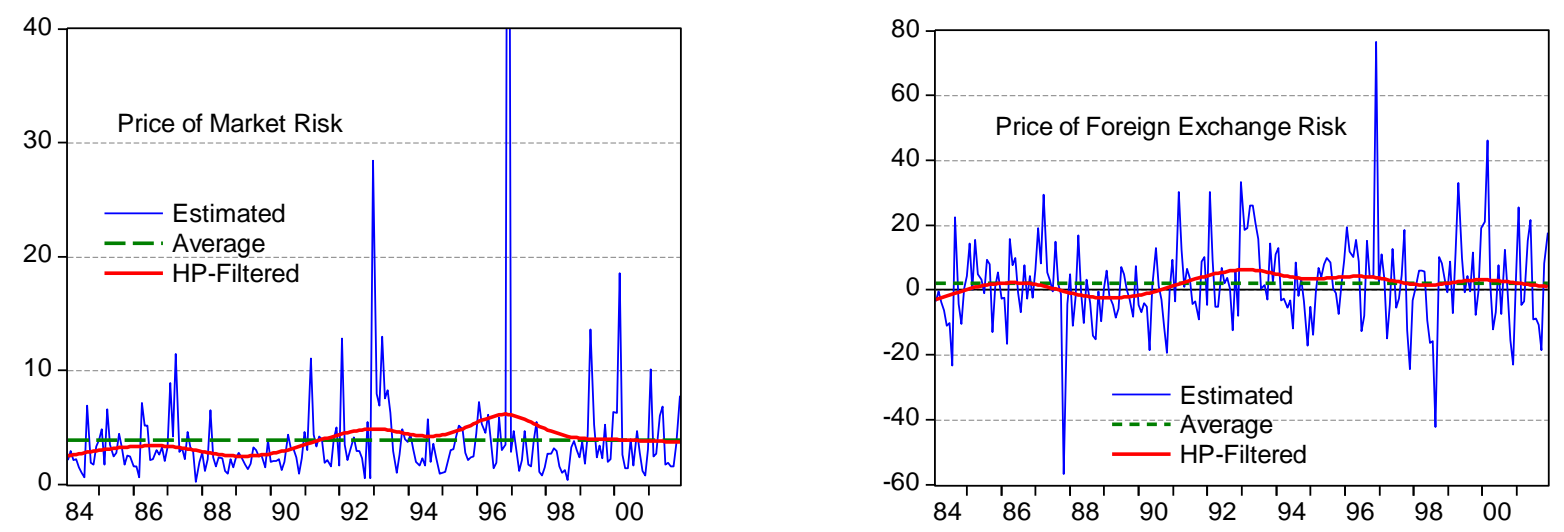


\section{Exhibit 2 Risk Premia Estimates}
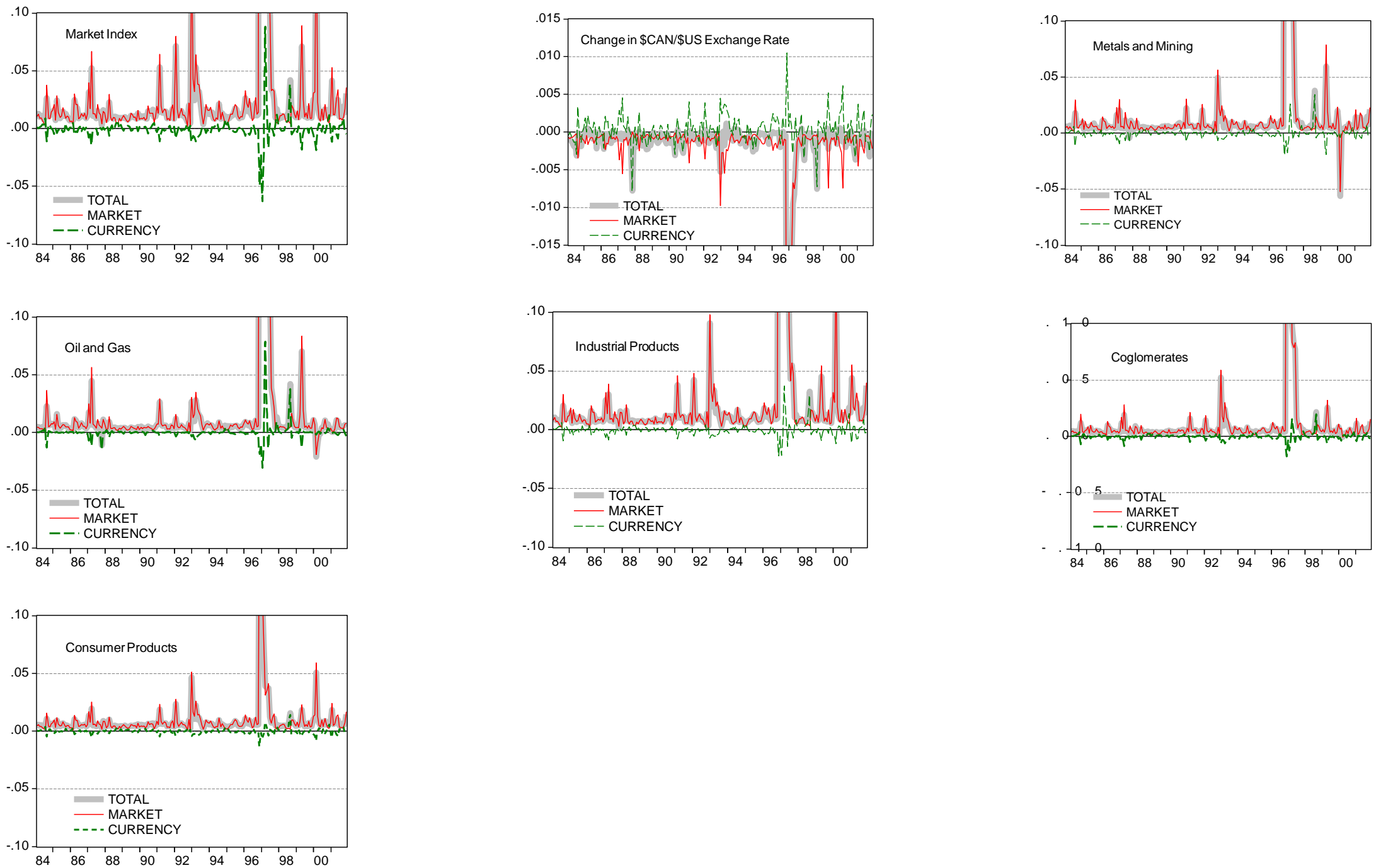
Table 7

Medians of the Top and Bottom Deciles for Estimated Total, Market, and Currency Risk Premia

The risk premia as computed as follows: Total premium, $T P_{i}=\hat{\lambda}_{F X} \hat{\sigma}_{i, F X}+\hat{\lambda}_{M} \hat{\sigma}_{i, M}$, Market premium, $M P_{i}=\hat{\lambda}_{M} \hat{\sigma}_{i, M}$, and Currency premium, $C P_{i}=\hat{\lambda}_{F X} \hat{\sigma}_{i, F X}$, where $\hat{\lambda}_{M}$ and $\hat{\lambda}_{F X}$ are estimated prices of the market and currency risks, $\hat{\sigma}_{i, M}$ and $\hat{\sigma}_{i, F X}$ are estimated conditional covariances of the return $i$ with the market and currency index.

\begin{tabular}{|c|c|c|c|c|c|c|c|}
\hline & $\begin{array}{c}\text { Metals and } \\
\text { Mining }\end{array}$ & Oil and Gas & $\begin{array}{c}\text { Industrial } \\
\text { Products }\end{array}$ & Conglomerates & $\begin{array}{l}\text { Consumer } \\
\text { Products }\end{array}$ & $\begin{array}{c}\text { Market } \\
\text { Index }\end{array}$ & Currency \\
\hline \multicolumn{8}{|c|}{ Total risk premia, 1984-1993: } \\
\hline Median of highest decile & 0.0177 & 0.0174 & 0.0264 & 0.0134 & 0.0137 & 0.0341 & 0.0003 \\
\hline Median of lowest decile & 0.0035 & 0.0025 & 0.0054 & 0.0027 & 0.0032 & 0.0070 & -0.0023 \\
\hline \multicolumn{8}{|c|}{ Market risk premia, 1984-1993: } \\
\hline Median of highest decile & 0.0234 & 0.0226 & 0.0320 & 0.0181 & 0.0165 & 0.0412 & -0.0002 \\
\hline Median of lowest decile & 0.0024 & 0.0020 & 0.0030 & 0.0015 & 0.0017 & 0.0041 & -0.0035 \\
\hline \multicolumn{8}{|c|}{ Currency risk premia, 1984-1993: } \\
\hline Median of highest decile & 0.0025 & 0.0013 & 0.0030 & 0.0018 & 0.0019 & 0.0040 & 0.0034 \\
\hline Median of lowest decile & -0.0065 & -0.0050 & -0.0058 & -0.0046 & -0.0039 & -0.0083 & -0.0020 \\
\hline \multicolumn{8}{|c|}{ Total risk premia, 1994-2001: } \\
\hline Median of highest decile & 0.1747 & 0.5775 & 0.2849 & 0.0901 & 0.0448 & 0.6148 & 0.0003 \\
\hline Median of lowest decile & 0.0037 & 0.0004 & 0.0065 & 0.0023 & 0.0039 & 0.0087 & -0.0089 \\
\hline \multicolumn{8}{|c|}{ Market risk premia, 1994-2001: } \\
\hline Median of highest decile & 0.1592 & 0.5559 & 0.2841 & 0.0831 & 0.0500 & 0.5625 & -0.0004 \\
\hline Median of lowest decile & 0.0020 & 0.0007 & 0.0039 & 0.0014 & 0.0020 & 0.0049 & -0.0075 \\
\hline \multicolumn{8}{|c|}{ Currency risk premia, 1994-2001: } \\
\hline Median of highest decile & 0.0052 & 0.0038 & 0.0083 & 0.0034 & 0.0031 & 0.0103 & 0.0030 \\
\hline Median of lowest decile & -0.0061 & -0.0118 & -0.0104 & -0.0042 & -0.0044 & -0.0184 & -0.0024 \\
\hline
\end{tabular}


Table 8

\section{Average Estimated Risk Premia}

The table contains the coefficient estimates of the regressions of the estimated risk premia from the model with time-varying risk on a constant and a dummy variable for the post-January 1994 period, where $D_{t}=1$, if $t>$ January 1994, and $D_{t}=0$ otherwise.

The risk premia as computed as follows: Total premium, $T P_{i}=\hat{\lambda}_{F X} \hat{\sigma}_{i, F X}+\hat{\lambda}_{M} \hat{\sigma}_{i, M}$, Market premium, $M P_{i}=\hat{\lambda}_{M} \hat{\sigma}_{i, M}$, and Currency premium, $C P_{i}=\hat{\lambda}_{F X} \hat{\sigma}_{i, F X}$, where $\hat{\lambda}_{M}$ and $\hat{\lambda}_{F X}$ are estimated prices of the market and currency risks, $\hat{\sigma}_{i, M}$ and $\hat{\sigma}_{i, F X}$ are estimated conditional covariances of the return $i$ with the market and currency index. Standard errors are computed using the Newey-West heteroskedasticity and autocorrelation robust procedure.

\begin{tabular}{|c|c|c|c|c|c|c|c|}
\hline & $\begin{array}{l}\text { Metals and } \\
\text { Mining }\end{array}$ & Oil and Gas & $\begin{array}{l}\text { Industrial } \\
\text { Products }\end{array}$ & Conglomerates & $\begin{array}{l}\text { Consumer } \\
\text { Products }\end{array}$ & $\begin{array}{c}\text { Market } \\
\text { Index }\end{array}$ & Currency \\
\hline $\begin{array}{c}\text { Total Premium: } \\
\text { Pre-1994 } \\
\text { t-stats } \\
\text { Prob. }\end{array}$ & $\begin{array}{c}0.0069^{* * *} \\
11.6460 \\
0.0000\end{array}$ & $\begin{array}{c}0.0064^{* * *} \\
8.9480 \\
0.0000\end{array}$ & $\begin{array}{c}0.0109^{* * * *} \\
9.9774 \\
0.0000\end{array}$ & $\begin{array}{c}0.0056^{* * *} \\
8.5787 \\
0.0000\end{array}$ & $\begin{array}{c}0.0064^{* * *} \\
10.9893 \\
0.0000\end{array}$ & $\begin{array}{c}0.0153^{\text {**** }} \\
8.4839 \\
0.0000\end{array}$ & $\begin{array}{c}-0.0009^{* * *} \\
-8.8113 \\
0.0000\end{array}$ \\
\hline $\begin{array}{c}\text { Change Post-1994 } \\
\text { t-stats } \\
\text { Prob. }\end{array}$ & $\begin{array}{l}0.0236 \\
1.3318 \\
0.1844\end{array}$ & $\begin{array}{l}0.0561 \\
1.3698 \\
0.1722\end{array}$ & $\begin{array}{l}0.0313 \\
1.6073 \\
0.1095\end{array}$ & $\begin{array}{l}0.0139 \\
1.3025 \\
0.1942\end{array}$ & $\begin{array}{l}0.0073 \\
1.4291 \\
0.1544\end{array}$ & $\begin{array}{l}0.0912 \\
1.3553 \\
0.1768\end{array}$ & $\begin{array}{c}-0.0015 \\
-1.3582 \\
0.1758\end{array}$ \\
\hline $\begin{array}{c}\text { Market premium: } \\
\text { Pre-1994 } \\
\text { t-stats } \\
\text { Prob. }\end{array}$ & $\begin{array}{c}0.0077^{* * *} \\
9.3663 \\
0.0000\end{array}$ & $\begin{array}{c}0.0070^{* * *} \\
7.6620 \\
0.0000\end{array}$ & $\begin{array}{l}0.0115^{* * *} \\
8.6111 \\
0.0000\end{array}$ & $\begin{array}{c}0.0061^{* * *} \\
7.2170 \\
0.0000\end{array}$ & $\begin{array}{c}0.0068^{* * *} \\
9.0633 \\
0.0000\end{array}$ & $\begin{array}{c}0.0162^{* * * *} \\
7.4312 \\
0.0000\end{array}$ & $\begin{array}{c}-0.0011^{* * *} \\
-7.5575 \\
0.0000\end{array}$ \\
\hline $\begin{array}{c}\text { Change Post-1994 } \\
\text { t-stats } \\
\text { Prob. }\end{array}$ & $\begin{array}{l}0.0231 \\
1.2868 \\
0.1996\end{array}$ & $\begin{array}{l}0.0551 \\
1.3482 \\
0.1790\end{array}$ & $\begin{array}{l}0.0310 \\
1.5779 \\
0.1161\end{array}$ & $\begin{array}{l}0.0137 \\
1.2529 \\
0.2116\end{array}$ & $\begin{array}{l}0.0073 \\
1.3734 \\
0.1711\end{array}$ & $\begin{array}{l}0.0913 \\
1.3421 \\
0.1810\end{array}$ & $\begin{array}{c}-0.0016 \\
-1.3183 \\
0.1888\end{array}$ \\
\hline $\begin{array}{c}\text { Currency premium: } \\
\text { Pre-1994 } \\
\text { t-stats } \\
\text { Prob. }\end{array}$ & $\begin{array}{c}-0.0007^{* *} \\
-2.4898 \\
0.0135\end{array}$ & $\begin{array}{c}-0.0006^{* *} \\
-2.4204 \\
0.0163\end{array}$ & $\begin{array}{c}-0.0006^{* *} \\
-2.0069 \\
0.0460\end{array}$ & $\begin{array}{l}-0.0005^{* *} \\
-2.2510 \\
0.0254\end{array}$ & $\begin{array}{c}-0.0003^{*} \\
-1.7701 \\
0.0781\end{array}$ & $\begin{array}{c}-0.0009^{* *} \\
-1.9930 \\
0.0475\end{array}$ & $\begin{array}{l}0.0002 \\
1.1257 \\
0.2615\end{array}$ \\
\hline $\begin{array}{c}\text { Change Post-1994 } \\
\text { t-stats } \\
\text { Prob. }\end{array}$ & $\begin{array}{l}0.0005 \\
0.6592 \\
0.5105\end{array}$ & $\begin{array}{l}0.0010 \\
1.0852 \\
0.2790\end{array}$ & $\begin{array}{l}0.0003 \\
0.3252 \\
0.7454\end{array}$ & $\begin{array}{l}0.0002 \\
0.4350 \\
0.6640\end{array}$ & $\begin{array}{c}0.0000 \\
-0.0068 \\
0.9946\end{array}$ & $\begin{array}{c}-0.0001 \\
-0.0554 \\
0.9559\end{array}$ & $\begin{array}{l}0.0001 \\
0.3315 \\
0.7406\end{array}$ \\
\hline
\end{tabular}

${ }^{* * *}$ indicates $1 \%$ significance, ${ }^{* *}$ indicates $5 \%$ significance, ${ }^{*}$ indicates $10 \%$ significance level. 
Table 9

\section{Average Estimated Risk Premia During Economic Shocks}

The table contains the parameter estimates of the regressions of the outliers (top 5\% and bottom 5\%) of the estimated risk premia from the model with time-varying risk on a constant and a dummy variable for the post-January 1994 period $\left(D_{t}=1\right.$, if $t>$ January 1994, and $\mathrm{D}_{\mathrm{t}}=0$ otherwise). The risk premia as computed as follows: Total premium, $T P_{i}=\hat{\lambda}_{F X} \hat{\sigma}_{i, F X}+\hat{\lambda}_{M} \hat{\sigma}_{i, M}$, Market premium, $M P_{i}=\hat{\lambda}_{M} \hat{\sigma}_{i, M}$, and Currency premium, $C P_{i}=\hat{\lambda}_{F X} \hat{\sigma}_{i, F X}$, where $\hat{\lambda}_{M}$ and $\hat{\lambda}_{F X}$ are estimated prices of the market and currency risks, $\hat{\sigma}_{i, M}$ and $\hat{\sigma}_{i, F X}$ are estimated conditional covariances of the return $i$ with the market and currency index. Standard errors are computed using the Newey-West heteroskedasticity and autocorrelation robust procedure.

\begin{tabular}{|c|c|c|c|c|c|c|c|}
\hline & $\begin{array}{l}\text { Metals and } \\
\text { Mining }\end{array}$ & Oil and Gas & $\begin{array}{c}\text { Industrial } \\
\text { Products }\end{array}$ & Conglomerates & $\begin{array}{c}\text { Consumer } \\
\text { Products }\end{array}$ & $\begin{array}{c}\text { Market } \\
\text { Index }\end{array}$ & Currency \\
\hline \multicolumn{8}{|l|}{ Total Premium: } \\
\hline Pre-1994 & $0.0106^{* * *}$ & $0.0123^{* *}$ & $0.0175^{* * *}$ & $0.0085^{* * *}$ & $0.0100^{* * * *}$ & $0.0262^{* * * *}$ & $-0.0018^{*}$ \\
\hline t-statistic & 3.5141 & 2.2784 & 3.7033 & 3.5588 & 3.4504 & 3.0732 & -2.0692 \\
\hline Probability & 0.0025 & 0.0351 & 0.0016 & 0.0022 & 0.0029 & 0.0066 & 0.0532 \\
\hline Change Post-1994 & $0.1859^{*}$ & $0.4076^{*}$ & $0.1973^{* *}$ & $0.1155^{*}$ & 0.0536 & $0.7438^{*}$ & -0.0113 \\
\hline t-statistic & 1.8315 & 1.7982 & 2.1721 & 1.8285 & 1.6422 & 2.0564 & -1.5745 \\
\hline Probability & 0.0836 & 0.0889 & 0.0435 & 0.0841 & 0.1179 & 0.0545 & 0.1328 \\
\hline \multicolumn{8}{|l|}{ Market premium: } \\
\hline Pre-1994 & $0.0145^{* * *}$ & $0.0169^{* *}$ & $0.0203^{* * *}$ & $0.0109^{* * *}$ & $0.0114^{* * *}$ & $0.0302^{* * *}$ & $-0.0021^{* * *}$ \\
\hline t-statistic & 3.3364 & 2.6247 & 3.1244 & 3.1302 & 3.0775 & 2.9566 & -2.8663 \\
\hline Probability & 0.0037 & 0.0172 & 0.0059 & 0.0058 & 0.0065 & 0.0084 & 0.0103 \\
\hline Change Post-1994 & 0.1844 & $0.4029^{*}$ & $0.2006^{*}$ & 0.1151 & 0.0545 & $0.7450^{*}$ & -0.0126 \\
\hline t-statistic & 1.6835 & 1.7735 & 1.9114 & 1.7113 & 1.5488 & 1.8956 & -1.5282 \\
\hline Probability & 0.1095 & 0.0931 & 0.0720 & 0.1042 & 0.1388 & 0.0742 & 0.1439 \\
\hline \multicolumn{8}{|l|}{ Currency premium: } \\
\hline Pre-1994 & -0.0026 & $-0.0040^{*}$ & -0.0017 & -0.0017 & -0.0009 & -0.0026 & 0.0000 \\
\hline t-statistic & -1.3430 & -1.8583 & -0.8509 & -1.1439 & -0.8576 & -0.9322 & 0.0158 \\
\hline Probability & 0.1960 & 0.0796 & 0.4060 & 0.2676 & 0.4024 & 0.3636 & 0.9875 \\
\hline Change Post-1994 & 0.0036 & 0.0094 & 0.0032 & 0.0017 & 0.0006 & 0.0016 & 0.0009 \\
\hline t-statistic & 0.5411 & 1.0359 & 0.4869 & 0.4268 & 0.2000 & 0.1022 & 0.4061 \\
\hline Probability & 0.5951 & 0.3140 & 0.6322 & 0.6746 & 0.8437 & 0.9198 & 0.6894 \\
\hline
\end{tabular}

${ }^{* * *}$ indicates $1 \%$ significance, ${ }^{* *}$ indicates $5 \%$ significance, ${ }^{*}$ indicates $10 \%$ significance level. 
Table 10

Average Prices of Risks During Shocks

The table contains the parameter estimates of the regressions of the outliers (top 5\% and bottom 5\%) of the estimated prices of the market and currency risks on a constant and a dummy variable for the post-January 1994 period $\left(D_{t}=1\right.$, if $t>J a n u a r y ~ 1994$, and $\mathrm{D}_{\mathrm{t}}=0$ otherwise). Standard errors are computed using the Newey-West heteroskedasticity and autocorrelation robust procedure.

\begin{tabular}{ccc}
\hline & Price of Market Risk & Price of Currency Risk \\
\hline Pre-1994 & $3.5150^{* * * *}$ & 1.5904 \\
t-stats & 8.8545 & 1.1029 \\
Prob. & 0.0000 & 0.2713 \\
& & 0.8083 \\
Change Post-1994 & 0.8655 & 0.3645 \\
t-stats & 0.7993 & 0.7159 \\
Prob. & 0.4250 & \\
\hline
\end{tabular}

${ }^{* * *}$ indicates $1 \%$ significance, ${ }^{* *}$ indicates $5 \%$ significance, ${ }^{*}$ indicates $10 \%$ significance level.

Table 11

Average Exposures at During Shocks

The table contains the parameter estimates of the regressions of the outliers (top 5\% and bottom 5\%) of the estimated conditional covariances of the returns with the market and currency index from the model with time-varying risk on a constant and a dummy variables for the post-January 1994 period $\left(D_{t}=1\right.$, if $t>$ January 1994, and $D_{t}=0$ otherwise). Standard errors are computed using the Newey-West heteroskedasticity and autocorrelation robust procedure.

\begin{tabular}{|c|c|c|c|c|c|c|c|}
\hline & $\begin{array}{c}\text { Metals and } \\
\text { Mining } \\
\end{array}$ & Oil and Gas & $\begin{array}{l}\text { Industrial } \\
\text { Products }\end{array}$ & Conglomerates & $\begin{array}{c}\text { Consumer } \\
\text { Products }\end{array}$ & $\begin{array}{c}\text { Market } \\
\text { Index }\end{array}$ & Currency \\
\hline \multicolumn{8}{|l|}{ Market exposure: } \\
\hline Pre-1994 & $0.0041^{* * *}$ & $0.0040^{* *}$ & $0.0047^{* * *}$ & $0.0027^{* * *}$ & $0.0027^{* * *}$ & $0.0062^{* * *}$ & $-0.0003^{* * *}$ \\
\hline t-stats & 2.8954 & 2.6745 & 4.0691 & 3.5786 & 4.7232 & 4.4938 & -4.8112 \\
\hline Prob. & 0.0096 & 0.0155 & 0.0007 & 0.0021 & 0.0002 & 0.0003 & 0.0001 \\
\hline Change Post-1994 & $0.0590^{*}$ & $0.1625^{*}$ & $0.0687^{*}$ & $0.0306^{*}$ & $0.0111^{*}$ & $0.2258^{*}$ & $-0.0031^{*}$ \\
\hline t-stats & 1.7882 & 1.7811 & 2.0315 & 1.7840 & 1.8922 & 1.8891 & -2.0640 \\
\hline Prob. & 0.0906 & 0.0918 & 0.0572 & 0.0913 & 0.0747 & 0.0751 & 0.0537 \\
\hline \multicolumn{8}{|l|}{ Currency exposure: } \\
\hline Pre-1994 & $-0.0002^{* *}$ & -0.0001 & $-0.0002^{* * *}$ & $-0.0002^{* *}$ & $-0.0001^{* * *}$ & $-0.0003^{* * *}$ & $0.0001^{* * *}$ \\
\hline t-stats & -2.6432 & -1.2806 & -2.9149 & -2.5941 & -4.7440 & -4.8112 & 21.4903 \\
\hline Prob. & 0.0165 & 0.2166 & 0.0092 & 0.0183 & 0.0002 & 0.0001 & 0.0000 \\
\hline Change Post-1994 & -0.0007 & $-0.0019^{* *}$ & $-0.0010^{* *}$ & -0.0005 & $-0.0002^{*}$ & $-0.0031^{*}$ & 0.0000 \\
\hline t-stats & -1.7086 & -1.8647 & -2.1612 & -1.6777 & -1.7967 & -2.0640 & 1.1589 \\
\hline Prob. & 0.1047 & 0.0786 & 0.0444 & 0.1107 & 0.0892 & 0.0537 & 0.2616 \\
\hline
\end{tabular}

${ }^{* * *}$ indicates $1 \%$ significance, ${ }^{* *}$ indicates $5 \%$ significance, ${ }^{*}$ indicates $10 \%$ significance level. 


\section{REFERENCES}

1. Adler, M. \& Dumas, B. (1983). International portfolio selection and corporation finance: A synthesis. Journal of Finance, 46, 925-984.

2. Baba, Y., Engel, R. F., Kraft, D. \& Kroner, K. (1990). Multivariate simultaneous generallized ARCH. Unpublished manuscript. University of California-San Diego.

3. Bollerslev, T. (1986). Generalized autoregressive conditional heteroscedasticity, Journal of Econometrics, 31, 307-327.

4. Carrieri, F., Errunza. V., \& Majerbi, B. (2003). Global price of foreign exchange risk. paper presented at Northern Finance Association meetings.

5. De Santis, G., Gerard, B., and P. Hillion, (2003) The relevance of currency risk in the EMU, Journal of Economics and Business 55, 427-462.

6. De Santis, G. \& Gerard, B. (1998). How big is the premium for currency risk? Journal of Financial Economics, 49, 375-412.

7. Dumas, B. \& Solnik, B. (1995) The world price of foreign exchange risk. Journal of Finance 50, 445-479.

8. Engle, R. F. \& Kroner, K. F. (1995). Multivariate simultaneous generalized ARCH. Econometric Theory, $11,122-150$.

9. $\quad$ Engle, R. \& Mezrich, J. (1996). GARCH for Groups, Risk, 9(8), 36-40.

10. Engle, R.F. (2002). Dynamic conditional correlation - A simple class of multivariate GARCH models. Journal of Business and Economic Statistics 20(3), 339-350.

11. Eviews 4.0 User's Guide (2002), Quantitative Micro Software.

12. Forbes K.J. and Rigobon, R. (2002), No contagion, only interdependence: measuring stock market comovements, Journal of Finance 57 (2002), 2223-2261.

13. Gourieroux, C. \& Jasiak, J. (2001). Financial Econometrics, Princeton University Press, Princeton, N.J.

14. Hansen, R. C., \& Song, M. H. (1998). Shareholder wealth effects of free trade: U.S. and Mexican stock market response to NAFTA. International Review of Economics \& Finance, 7(2), 209-224.

15. Hodrick, R. J., \& Prescott, E. C. (1997). Postwar U.S. Business Cycles: An Empirical Investigation. Journal of Money, Credit and Banking, 29(1), 1-16.

16. Karolyi, G. A. \& Stulz, R. (1996). Why do markets move together? An investigation of U.S. - Japan stock return comovements. The Journal of Finance, 51, 951-986.

17. Kroner, K.F. \& Ng, V. (1998). Modeling Asymmetric Comovements of Asset Returns. The Review of Financial Studies, 11(4), 817-844.

18. Obstfeld, M. (1994), Risk-taking, global diversification, and growth, American Economic Review 84, 13101329.

19. Rodriguez, P. L. (2003). Investor expectations and the North American Free Trade Agreement. Review of International Economics, 11, 206-218.

20. Sharpe, William F., Capital Asset Prices: A Theory of Market Equilibrium under Conditions of Risk, Journal of Finance, Vol. 19, No. 3 (Sep., 1964): 425-442.

21. Sharpe, William F., Risk-Aversion in the Stock Market: Some Empirical Evidence, Journal of Finance 20, No. 3 (Sep., 1965): 416-422.

22. Solnik, B. \& McLeavey, D. (2002). International Investments, 5th edition, Addison-Wesley, 2002.

23. Thompson, A. J. (1994). Trade liberalization, comparative advantage, and scale economies stock market evidence from Canada. Journal of International Economics, 37(1-2), 1-27.

24. Tsay, R.S. (2002). Analysis of Financial Time Series, John Wiley and Sons.

25. Tse, Y.K. (2000) A test for constant correlations in a multivariate GARCH model. Journal of Econometrics, 98, 107-127.

26. Turtle, H., Buse, A. \& Korkie, B. (1994). Tests of conditional asset pricing with time-varying moments and risk prices. Journal of Financial and Quantitative Analysis 29(1),15-29. 


\section{END NOTES}

\footnotetext{
${ }^{\mathrm{i}}$ See for example Thompson (1994) and Obstfeld (1994)..

ii Engle (2002) provides a comprehensive survey of literature on GARCH modeling. Gourieroux and Jasiak (2001) and Tsay (2002) present a survey of several versions of MGARCH models. Engle and Kroner (1995) refer to the model used in Baba et al. (1990) as BEKK.

${ }^{\text {iii }}$ Vech representation uses the lower part of the variance-covariance matrix $\mathbf{H}$ in the vector form; diagonal representation restricts elements of $\mathbf{H}$ to depend only on parameters with the same coefficient indices.

${ }^{\text {iv }}$ CFMRC stands for Canadian Financial Market Research Centre.

${ }^{v}$ Given Canada's heavy reliance on trade with the U.S., the exchange rate used here is the exchange rate of Canadian dollar visà-vis US dollar.

${ }^{\text {vi }}$ See De Santis and Gerard (1998).

${ }^{\text {vii }}$ A refinement of BHHH (Bernt, Hall, Hall and Hausman (1974)) algorithm, see EViews 4.1 manual.

viii Data series on Canadian bonds, originally compiled by Scotia-McLeod, reported in CANSIM database is discontinued in April, 2002.

ix Aaa-rated bond yields are not available over the entire period of our study.

${ }^{\mathrm{x}}$ As a robustness test, we also conduct the estimation with the value-weighted index and obtain similar results.

${ }^{x i}$ Statistical insignificance of some of the mean equation coefficients may be due to multicolinearity given the high level of correlations between some of the variables reported in Tables 1 and 2. However, the results of Likelihood Ratio test of joint hypotheses, reported in Table 5, indicate that the prices of market and currency risks are simultaneously equal to zero is rejected.

${ }^{x i 1}$ Hodrick-Prescott filter is a smoothing algorithm designed to reduce the noise in the estimated signal. See Hodrick and Prescott (1997).

xiii We do not present descriptive statistics for the estimated risk premia here; they are available on request from the authors.

${ }^{\text {xiv }}$ We aim to measure the ranges of values for the estimated risk premia and at the same time try to mitigate the impact of estimation errors. This is why we do not just present maximum and minimum values for the estimated risk premia, but use medians of the top and bottom deciles.

${ }^{x v}$ We believe this effect is due to increased market interdependence as government controls over cross-border capital flows are gradually removed. See Forbes and Rigobon (2002) for evidence on stock market interdependence.

xvi January 1, 1994 is the day when NAFTA came into effect. It is recognized that not only NAFTA, but also many other international events, such as FTA of 1987, and introduction of Euro are parts of a general trend towards globalization and deregulation of financial markets. We consider NAFTA to be a key event in the integration of Canadian economy with the other North American economies. Choice of the time of introduction of NAFTA as a break point to divide our study period into two sub-periods is somewhat arbitrary. We consider globalization as an ongoing process, and introduction of NAFTA to be an important landmark in that process. Therefore, by dividing the sample into pre-NAFTA and post-NAFA sub-samples, we in effect study whether the characteristics of the Canadian stock market changed as the process of globalization progressed, and we do not claim that NAFTA alone was the cause of such changes.

${ }^{x v i i}$ We also find no significant changes in the average prices of market and currency risks, as well as in the average market and currency exposures. We do not present these results here but they are available upon request from the authors.

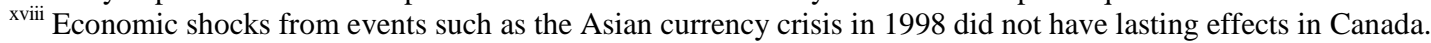

